Pesq. Vet. Bras. 35(12):997-1001, dezembro 2015 DOI: $10.1590 / \mathrm{S} 0100-736 \mathrm{X} 2015001200009$

\title{
Osteology and radiographic anatomy of the hind limbs in Marshdeer (Blastocerus dichotomus) ${ }^{1}$
}

\author{
Bruno C. Schimming ${ }^{2 *}$, Sheila C. Rahal ${ }^{3}$, Daniela A. Shigue ${ }^{3}$, Juliana L. Linardi ${ }^{4}$, Luiz \\ C. Vulcano ${ }^{5}$ and Carlos R. Teixeira ${ }^{3}$
}

\begin{abstract}
Schimming B.C., Rahal S.C., Shigue D.A., Linardi J.L., Vulcano L.C. \& Teixeira C.R. 2015. Osteology and radiographic anatomy of the hind limbs in Marshdeer (Blastocerus dichotomus). Pesquisa Veterinária Brasileira 35(12):997-1001. Departamento de Anatomia, Universidade Estadual Paulista, Cx. Postal 510, Botucatu, SP 18618-970, Brazil. E-mail: bruno@ibb.unesp.br

The knowledge of anatomical structures found in wild animals is important for the practice of medical and surgical clinic. Thus, the aim of this study was to describe the osteology and radiographic anatomy of the femur, patella, tibia, fibula, tarsal, metatarsal and phalanges of the Marshdeer Blastocerus dichotomus as a reference for clinical use and species identification. Most structures were similar to those found in domestic animals, with special features of this species. Noteworthy is, for example, the absence of the third trochanter of the femur. Although a ruminant, the Marshdeer has a fibuyla similar to the one described for the horse. B. dichotomus has four fingers on each limb, formed through three phalanges, only the third and fourth finger touch the ground, and the second and fifth finger is rudimentary. It has four proximal and two distal sesamoid bones, and sesamoid bones near the gastrocnemius muscle do not exist.
\end{abstract}

INDEX TERMS: Marshdeer, Blastocerus dichotomus, thigh, leg, wild animals, anatomy.

RESUMO.- [Anatomia óssea e radiográfica do membro pélvico do cervo-do-pantanal (Blastocerus dichotomus).] 0 conhecimento das estruturas anatômicas encontradas nos animais silvestres é importante para a prática da clínica médica e cirúrgica. 0 objetivo deste trabalho foi descrever a osteologia e anatomia radiográfica do fêmur, patela, tíbia, fíbula, tarsais, metatarsais e falanges do cervo-do-pantanal, para contribuir com o cotidiano clínico e, a identificação da espécie. A maioria das estruturas foi semelhante às encontradas nos animais domésticos, com parti-

\footnotetext{
${ }^{1}$ Received on June 18, 2015.

Accepted for publication on September 22, 2015.

${ }^{2}$ Departamento de Anatomia, Instituto de Biociências de Botucatu, Universidade Estadual Paulista Júlio de Maesquita Filho (Unesp), Distrito de Rubião Junior s/n, Cx. Postal 510, Botucatu, SP 18618-970, Brazil. *Corresponding author: bruno@ibb.unesp.br

${ }^{3}$ Centro de Medicina e Pesquisa em Animais Selvagens (CEMPAS), Faculdade de Medicina Veterinária e Zootecnia, Unesp, Campus de Botucatu, Distrito de Rubião Júnior s/n, Botucatu, SP 18618-970.

${ }^{4}$ Centro de Conservação do Cervo do Pantanal, GAE-CCCP, CESP, Rodovia BR-153 Km 139, Promissão, SP 16370-000, Brazil.

${ }^{5}$ Departamento de Reprodução Animal e Radiologia Veterinária, Faculdade de Medicina Veterinária e Zootecnia, Unesp, Campus de Botucatu, Distrito de Rubião Júnior s/n, Botucatu, SP 18618-970.
}

cularidades próprias da espécie. Destaca-se, por exemplo, a ausência do terceiro trocanter do fêmur. Embora seja um ruminante, o cervo-do-pantanal apresentou a fíbula semelhante à descrita para os equinos. Este animal possui quatro dedos em cada membro, formados por três falanges, sendo que apenas o terceiro e o quarto dedos tocam o solo e, o segundo e o quinto dedos são rudimentares. Apresentou ainda quatro ossos sesamóides proximais e dois distais. Não se observou ossos sesamóides junto ao músculo gastrocnêmio.

TERMOS DE INDEXAÇÃO: Cervo-do-pantanal, Blastocerus dichotomus, coxa, perna, animais silvestres, anatomia.

\section{INTRODUCTION}

The Marshdeer is a ruminant that belongs to the family Cervidae included on the currently eight species of deer found in Brazil (Barbanti Duarte 2008, Barbanti Duarte et al. 2012). This species is considered the largest deer from South America, and the males can weigh up to $130 \mathrm{~kg}$ (Pinder \& Grosse 1991). The muzzle and limbs below the carpal and tarsal joints are black as well as distal end of the tail, eyelids and eyelashes (Pinder \& Grosse 1991, Piovezan 2004). In addition, the Marshdeer is distinguished from other cer- 
vids because the fur is wooly with long and uniform light brown color bristle, except for the abdomen, inner portion of the thighs, neck, inside of the ears and around the eyes where the color is white (Piovezan 2004). The body pelage has reddish-brown color, specially in the summer (Pinder \& Grosse 1991). This animal is typical from marsh habitats and seasonally flooded riverine areas, which led to acquire adaptive anatomical features such as the presence of webbing, markedly elongated hoofs, and relatively long limbs (Tomas et al. 1997).

The Marshdeer is a species with increased conservation concern (Barbanti Duarte 2008, Barbanti Duarte et al. 2012). The population has declined more and more, mainly by anthropogenic perturbations in the environment (Ríos-Uzeda 2008). Diseases introduced by cattle, drainage floodplains and other wetlands for agriculture projects, and the poor protection offered by national parks and reserves are among the causes of mortality and decline of the population (Tomas et al. 1997, Tiepolo et al. 2004). Studies on the management of deer capture for monitoring was cited that the decline in the deer population in several South America marshlands was due to the loss of available habitat caused by human activities, especially construction of hydroelectric dams (Barbanti Duarte 2008). This type of construction destroys the marginal habitats along the major rivers, eliminating the floodplains, virtually nullifying any possibility of survival and sustainability of populations (Pinder 1996, Tomas et al. 1997). However, the extinction risk may be diminished mainly by knowledge creation about the species (Polegato 2008).

The number of studies involving wild animals from Brazil have increase due mainly to the importance of wildlife conservation presented by some species (Menezes et al. 2003, Martinez et al. 2013). The anatomical knowledge is fundamental to improve the preservation of local wildlife since may help improve medical and surgical treatments. Thus, the aim of this study was to describe the bone structures of the hind limbs in the Marshdeer.

\section{MATERIALS AND METHODS}

This study followed the guidelines for the care and use of laboratory animals and was approved by the Animal Use and Ethics Committee (626/2014) and by the National Environmental and Wildlife Bureau.
Four hind limbs of two adult Marshdeer (Blastocerus dichotomus) were used. The animals had died for reasons unrelated to this study. All animals had originated from conservation breeding of the Marshdeer sponsored by the Energy Company of São Paulo - CESP (Conservation Center of the Marshdeer, GAE-CCCP, CESP), Promissão, São Paulo, Brazil.

The specimens were collected immediately after the animals had died and stored at $-20^{\circ} \mathrm{C}$. For radiographic examinations the limbs were defrosted, and the images were acquired in craniocaudal, and mediolateral views. A digital radiographic system was used (EZy-Rad Pro X-ray system, Shimadzu; Console Advance, DR-ID 300CL, Fujifilm) with focus-film distance of $100 \mathrm{~cm}$ and an exposure of $70 \mathrm{kV}, 200 \mathrm{~mA}, 6.4 \mathrm{mAs}$.

After this, the hind limbs were dissected and subjected to water maceration. The maceration fluid was prepared by combining 1 part of solution of hydrogen peroxide (130 volume concentration) to 40 parts water (Rodrigues 2005). The bones were identified, described, photodocumented, and named according to Nomina Anatomica Veterinaria (International Committe on Veterinary Gross Anatomical Nomenclature 2012).

\section{RESULTS}

The femur was the largest bone in the Marshdeer hind limb. It has a body and two extremities more developed, the proximal and distal epiphyses. The proximal extremity showed the femoral head with a slightly pronounced fovea. The femoral neck surrounds the head and is best evidenced medially. The greater trochanter is lateral and divided into cranial and caudal portions. There was not trochanteric notch. The intertrochanterics crest and line, and trochanteric fossa were seen. The femoral body was the central shaft between the extremities. The lesser trochanter appeared in the body. There were well-developed muscle lines, caudally, in the body. The third trochanter was not found in the Marshdeer femur (Fig.1a, 3a-c). The trochlea was identified cranially in the femoral distal extremity. The trochlea was formed by two trochlear crests, medial and lateral crests. The medial trochlear crest is more prominent that lateral crest. The trochlear groove appeared between the trochlear crests. The medial and lateral condyles were separated by the intercondylar fossa (Fig.3a). The lateral condyle was greater than the medial condyle. There were also the medial and lateral epicondyles. The lateral epicondyle was also the most developed. The supracondilar fossa was pro-

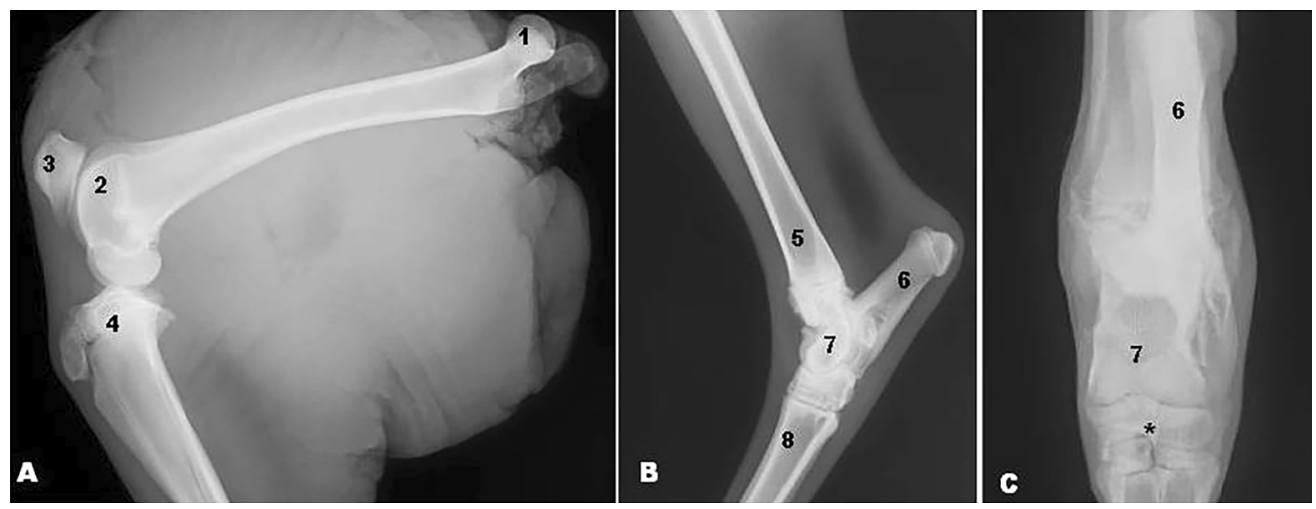

Fig.1. (A,B) Mediolateral and (C) craniocaudal radiographic view of the Marshdeer hind limbs showing (1) femoral head, (2) femoral trochlea, (3) patella, (4) tibia, (5) distal epiphysis of tibia, (6) calcaneus, (7) talus, (8) metatarsal bone, and $\left({ }^{*}\right)$ centroquartal bone. 


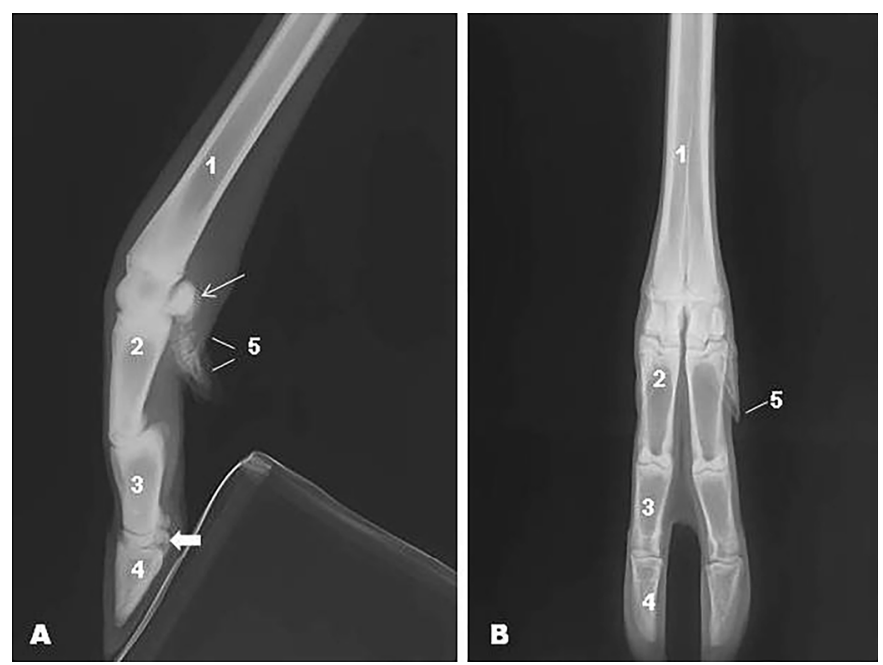

Fig.2. (A) Mediolateral and (B) craniocaudal radiographic view of the Marshdeer showing (1) metatarsal bone, (2) proximal phalange, (3) middle phalange, (4) distal phalange, (5) phalanges of the rudimentar fingers, (thin arrow) proximal sesamoid bones and (thick arrow) distal sesamoid bones.
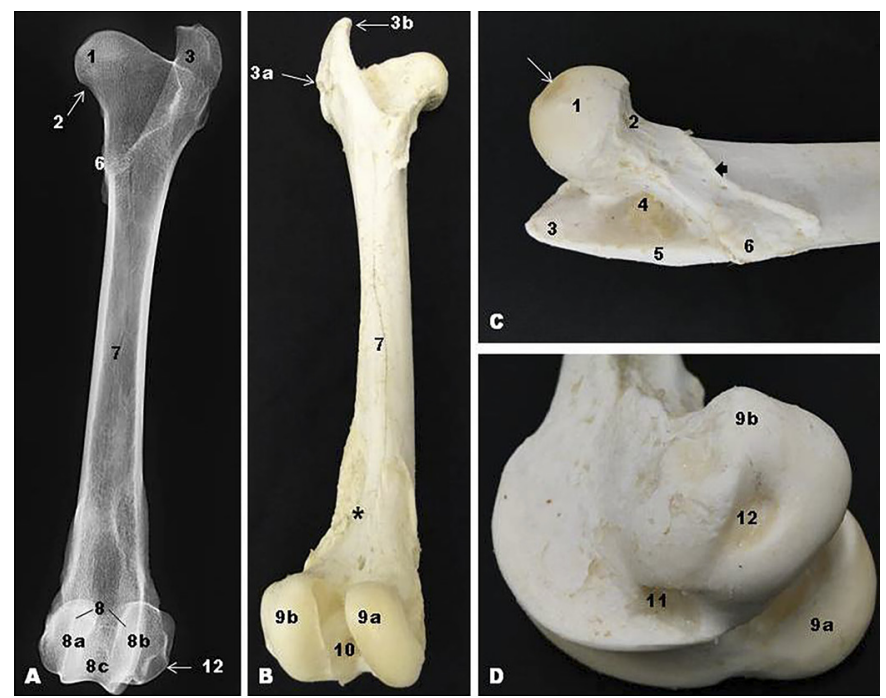

Fig.3. (A-D) Marshdeer femur. Craniocaudal radiographic view. Noted (1) femoral head, (2) femoral neck, (3) greater trochanter, (3a) cranial portion of the greater trochanter, (3b) caudal portion of the greater trochanter, (4) trochanteric fossa, (5) intertrochanteric crest, (6) lesser trochanter, (7) femoral body, (8) femoral trochlea, (8a) medial trochlear crest, (8b) lateral trochlear crest, (8c) trochlear groove, (9a) medial condyle, (9b) lateral condyle, (10) intercondylar fossa, (11) extensor fossa, (12) popliteal muscle fossa, (thin arrow) fovea of the femoral head, (thick arrow) intertrochanteric line, and (asterisk) supracondilar fossa.

minent (Fig.3b). The lateral condyle showed deep extensor fossa, and caudally, a depression that corresponds to the popliteal muscle fossa (Fig.3a,d).

Patella was a triangular, narrow and thick bone, with the base facing upward and the apex pointed face down. The patella presented two surfaces and two borders. The surfaces were cranial and articular, and borders were medial and lateral. The cranial surface was convex and quite irregular (Fig.1a, 4a,b).
Tibia and fibula were found in the Marshdeer leg (Fig.5a-d). Tibia was a long bone with a body and two extremities. The proximal extremity was wider than the distal and with irregular contour. The tibia presented two condyles - lateral and medial condyles - that articulated with the corresponding condyles of the femur. Between the condyles appeared the intercondylar eminence, with medial and lateral intercondylar tubercles. The intercondylar areas were found cranial and caudal to the intercondylar eminence. Cranially, was observed an extensive eminence, the tibial tuberosity. The tibial tuberosity was separated from the lateral condyle by extensor groove, which is a notch that allows the passage of the common tendon of origin of the third fibular and long digital extensor muscles (Fig.5c). The tibial body was wide, with three surfaces: medial, lateral and caudal. The caudal face showed muscle lines proximal and caudally. The distal extremity was quadrilateral, more
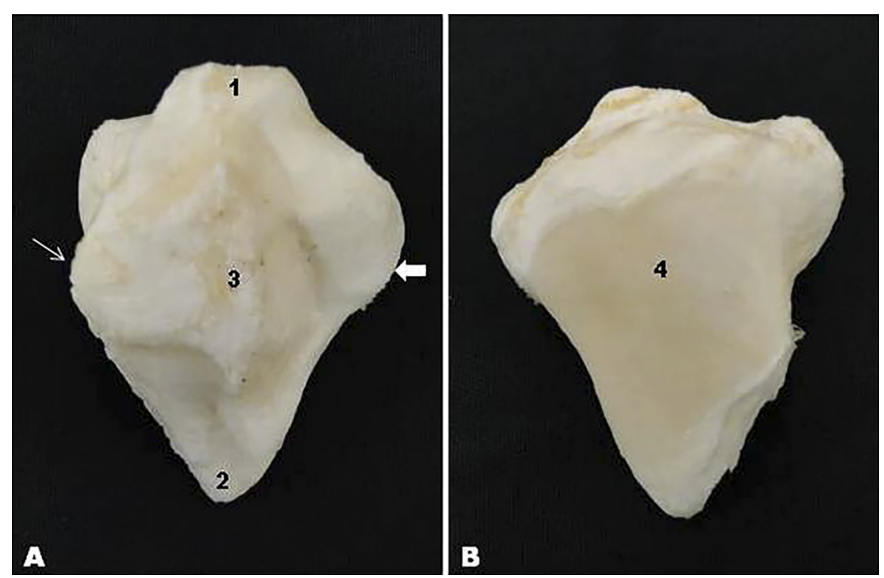

Fig.4. Marshdeer patella. (1) patella base, (2) patella apex, (3) cranial surface, (4) articular surface, (thin arrow) medial border, and (thick arrow) lateral border.
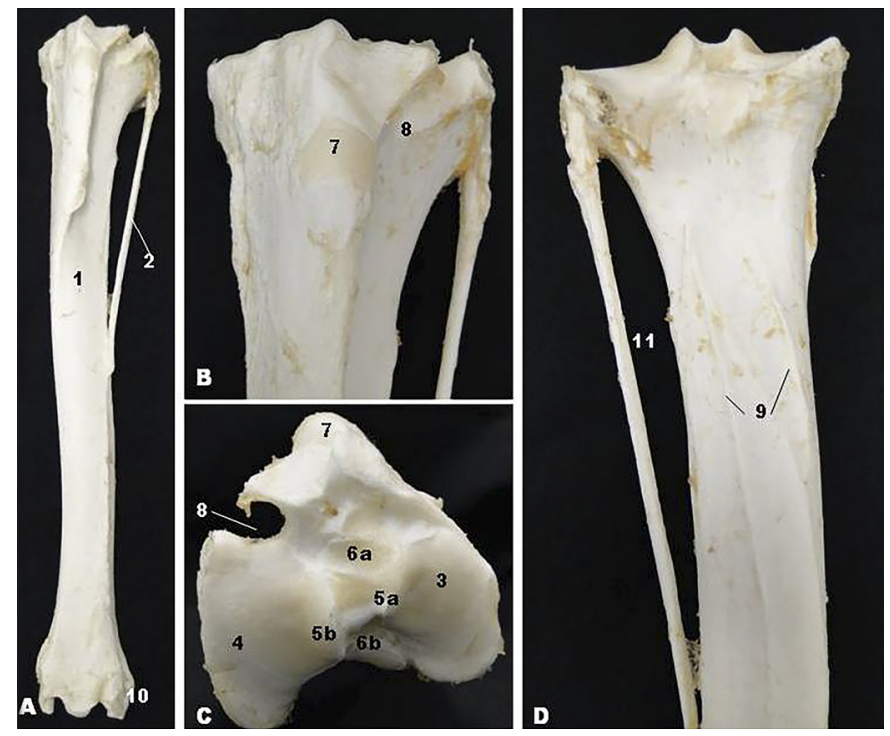

Fig.5. Marshdeer tibia and fibula. (1) tibia, (2) fibula, (3) medial condyle, (4) lateral condyle, (5a) medial intercondylar tubercle, (5b) lateral intercondylar tubercle, (6a) cranial intercondylar area, (6b) caudal intercondylar area, (7) tibial tuberosity, (8) extensor groove, (9) muscle lines, (10) lateral maleolus, and (11) interosseus space. 


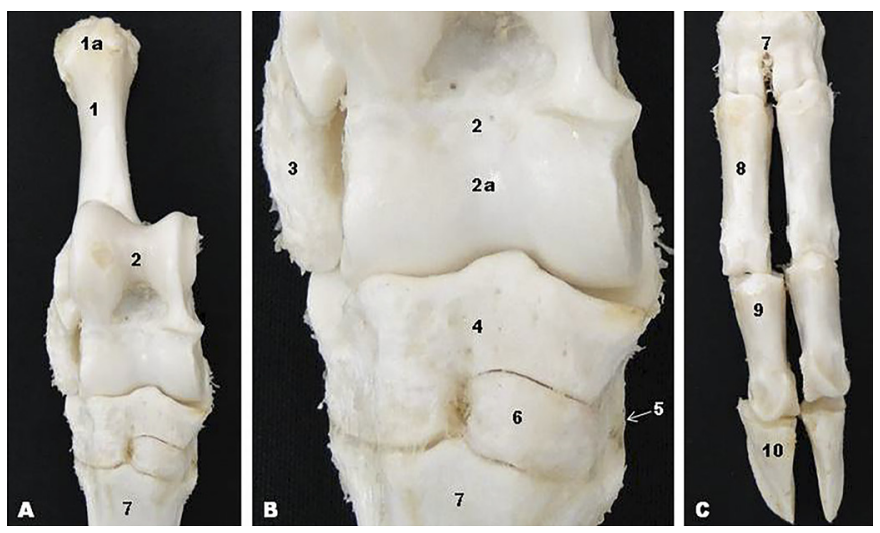

Fig.6. Marsh deer tarsus. (1) calcaneus, (1a) calcaneal tuberosity, (2) talus, (2a) trochlea of the talus, (3) proeminence for insertion of the lateral collateral ligament, (4) centroquartal bone, (5) I tarsal bone, (6) II and III tarsal bone, (7) III and IV metatarsal bone, (8) proximal phalange, (9) middle phalange, and (10) distal phalange.

developed than the body but smaller than the proximal extremity. It presented the articular surface to the tarsal that can be called cochlea of the tibia, which adapts to the trochlea of the talus (Fig.5a). The medial and lateral malleoli were observed (Fig.5a).

The Marshdeer fibula consisted of a long bone, underdeveloped, with incomplete sketch, found laterally to the tibia (Fig.5a,d). The fibula comprised of a body and two extremities. The proximal extremity comprised the fibular head and was articulated to the lateral condyle of the tibia, and the distal extremity joins to the tibia and fused with it. The body of the fibula was slender and usually ended in the middle third of the tibia. The interosseous space was located between the lateral border of the tibia and fibula shaft (Fig.5d).

The bones of the Marshdeer foot comprised the tarsal, metatarsal, and the bones of the fingers. The tarsal were divided into proximal and distal rows. The talus and calcaneus appeared in the proximal row. The talus was medial and had the trochlea for articulation with the distal epiphysis of the tibia (tibial cochlea) (Fig.1b,c, 6a,b). The calcaneus was lateral and proximally presented calcaneal tuberosity (Fig.6a). In the distal row were found centroquartal bone (fusion of central tarsal and fourth tarsal (IV) bones), first tarsal bone (I), and the second and third tarsal bones fused into a single bone (II and III)(Fig. 6b). The metatarsal bone was formed by the fusion of the third (III) and fourth (IV) metatarsal bones.

The Marshdeer had four fingers in the hind limbs, two are well developed and touch the ground, the third and fourth fingers, and two are rudimentary or vestigial, that are the second and fifth fingers, which appear on the plantar surface of the metatarsophalangeal joint (fetlock joint). Each finger had three phalanges, including rudimentary fingers, which had undeveloped phalanges, and the distal phalange was involved by hoof (Fig.2a,b, 6c). There were four proximal sesamoid bones near the metatarsophalangeal joint, in the plantar surface of the metatarsal bone. There were also two small distal sesamoid bones on the plantar surface of the distal interphalangeal joint. Sesamoid bones along the gastrocnemius muscle were not observed (Fig.2a).

\section{DISCUSSION}

The Marshdeer is an animal that typically appears in marshy areas (Tomas et al. 1997). The hind limbs are more developed than forelimbs, which enables the development of big boost when the animals are in danger and undertake escaping from predators. Marshdeer (Blastocerus dichotomus) is a ruminant, thus showed some bone features similar to that presented by other ruminant, although they also present differences when compared with domestic ruminants such as cattle.

The femur was the largest bone found in the Marshdeer hind limb, that is a common to other mammals. This bone presented only greater and lesser trochanter. The third trochanter was not seen, unlike to horse and cattle (Getty 1986), mole-rat (Ozkan 2002), agouti (Oliveira et al. 2009), paca (Oliveira et al. 2007, Araújo et al. 2013), capybara (Araújo et al. 2013), and ring-tailed lemurs (Makungu et al. 2013). Paca and capybara have a third trochanter undeveloped (Araújo et al. 2010, 2013). Ribeiro et al. (2013) do not mention the presence of the third trochanter in the giant anteater femur. The morphology of the femoral distal epiphysis was similar to that described for cattle (Getty 1986). Oliveira (2001) and Ribeiro et al. (2013) reported that the differences found in the mammals' femur are related to adaptive aspects of animals to different lifestyles. As has been said that morphology is a plastic image of the function, we suggest that not only the differences found in the femur, or in the hind limb and, more broadly, all differences found in a species, really, should this fact.

The bones involved in the knee joint are femur, tibia and patella. The patella is larger sesamoid bone found in the animal body and their morphology was similar to found in the lion (Kirberger et al. 2005) and Indian muntjac (Rajani et al. 2013). In Marshdeer, like other ruminants such as cattle (Getty 1986), no other sesamoid bones was observed in this joint, even when analyzes were performed on radiographs. Sesamoid bones have been reported in the stifle joint of the dog (Evans \& De Lahunta 2013), of the ring-tailed lemur (Makungu et al. 2013), and in the gastrocnemius muscle in the paca (Araújo et al. 2013).

The presence or absence of sesamoid bones in the gastrocnemius muscle is much discussed in the literature. The sesamoid bone appear laterally in some animals such as the paca (Araújo et al. 2013), while in others animals they are not found, such as the capybara (Araújo et al. 2013). Ribeiro et al. (2013) did not show the presence of these sesamoid bones in the giant anteater. Even through anatomical and radiographic studies was not possible to demonstrate the presence of these sesamoid bones of the gastrocnemius muscle in the Marshdeer.

Tibia was a well developed bone, and fibula bone was a reduced long bone that joins to tibia in its middle third in the Marshdeer, similar to described in the horse. This differs from that occurring in domestic ruminants in which the fibula is very little developed, and the ends are connec- 
ted by a fibrous structure (Getty 1986). The fibula in the Marshdeer was also different from that found in the Indian muntjac deer (Rajani et al. 2013), in wild rodents such as paca and capybara (Araújo et al. 2013), and the giant anteater (Ribeiro et al. 2013). The fibula in the Indian muntjac deer comprised of only two extremities similar to domestic cattle (Rajani et al. 2013).

The bone structure found at the Marshdeer foot was similar to reported in domestic cattle (Getty 1986), with tarsal bones appeared into proximal and distal rows. The proximal row comprised talus and calcaneus bones; and in the distal row were found centroquartal, first tarsal bone (I) and the second and third tarsal bones fused into a single bone (III and IV). The metatarsal is also divided into third (III) and fourth (IV) metatarsal in the Marshdeer.

Cervids are characterized by the presence of hoof entirely overlying the four fingers on each limb, and that only two fingers rest on the ground (Barbanti Duarte \& Merino 1997). In our study, each finger was composed of three phalanges, and the distal phalange of each finger was wrapped in the hull.

This paper presents a morphological description of the hind limb bones in the Marshdeer. This study revealed that there are many similarities in the hind limb bones of the Marshdeer and domestic ruminants, but there are also significant differences between these species. The findings are important to increase the knowledge of the Marshdeer and to support other investigations of this deer species.

\section{REFERENCES}

Araújo F.A.P., Rahal S.C., Doiche D.P., Machado M.R.F., Vulcano L.C., Teixeira C.R. \& El-Warrak A.O. 2010. Imaging studies of the hindlimbs of pacas (Cuniculus paca) bred in captivity. Vet. Comp. Orthop. Traumatol. 6:439443.

Araújo F.A.P., Sesoko N.F., Rahal S.C., Teixeira C.R., Müller T.R. \& Machado M.R.F. 2013. Bone morphology of the hind limbs in two caviomorph rodents. Anat. Histol. Embryol. 42:114-123.

Barbanti Duarte J.M. 2008. A technique for the capture of free-ranging Marshdeer (Blastocerus dichotomus). J. Zoo Wildl. Med. 39:596-599.

Barbanti Duarte J.M. \& Merino M.L. 1997. Taxonomia e evolução, p.2-21. In: Barbanti Duarte J.M. (Ed.), Biologia e conservação de cervídeos sul-americanos: Blastocerus, Ozotoceros e Mazama. Funep, Jaboticabal, 238p.

Barbanti Duarte J.M., Piovezan U., Zanetti E.S. \& Ramos H.G.C. 2012. Espécies de cervídeos brasileiros com preocupações de conservação. p.29-40. In: Barbanti Duarte J.M \& Reis M.L. (Eds), Plano de Ação Nacional para Conservação de Cervídeos Ameaçados de Extinção. ICMBio, Brasília, FDD.

Evans H.E. \& De Lahunta A. 2013. Miller's Anatomy of the dog. 4th ed. Saunders Elsevier, St. Louis. 872p.

Getty R. 1986. Sisson/Grossman Anatomia dos Animais Domésticos. 5aㅡ ed. Guanabara-Koogan, Rio de Janeiro. 1134p.

International Committee on Veterinary Gross Anatomical Nomenclature 2012. Nomina Anatomica Veterinária. 5th ed. World Association on Veterinary Anatomist, Knoxville. 177p.
Kirberger R.M., Du Plessis W.M. \& Turner P.H. 2005. Radiology anatomy of the normal appendicular skeleton of the lion (Panthera leo). 2. Pelvic limb. J. Zoo Wildl. Med. 36:29-35.

Martinez A.C., Oliveira F.S., Abreu C.O., Martins L.L., Pauloni A.P. \& Moreira N. 2013. Colheita de sêmen por eletroejaculação em cutia-parda (Dasyprocta azarae). Pesq. Vet. Bras. 33:86-88.

Makungu M., Groenewald H.B., du Plessis W.M., Barrows M. \& Koeppel K.N. 2013. Osteology and radiographic anatomy of the pelvis and hind limb of healthy ring-tailed lemurs (Lemur catta). Anat. Histol. Embryol. 42:1-13.

Menezes D.J.A., Carvalho M.A.M., Assis-Neto A.C., Oliveira M.F., Farias E.C., Miglino M.A. \& Medeiros G.X. 2003. Morfologia dos órgãos genitais externos do macho de cutia (Dasyprocta aguti Linnaeus, 1766). Braz. J. Vet. Res. Anim. Sci. 40:148-153.

Oliveira M.F. 2001. Morfologia funcional e desenho corporal da cintura pélvica e membros posteriores dos tamanduás (Mammalia: Xenarthra: Myrmecophagidae). Dissertação de Mestrado, Universidade Federal do Pará, Belém, PA. 90p.

Oliveira F.S., Canola J.C., Machado M.R.F. \& Camargo M.H.B. 2007. Descrição anátomo-radiográfica do esqueleto apendicular da paca (Agouti paca). Acta Scient. Vet. 35:83-87.

Oliveira F.S., Martins L.L., Pauloni A.P., Toniollo G.H., Canola J.C. \& Machado M.R.F. 2009. Descrição anátomo-radiográfica do esqueleto apendicular da cutia (Dasyprocta azarae, Lichtenstein, 1823). Ars Vet. 25:28-31.

Ozkan Z.E. 2002. Macro-anatomical investigations on the hind limb skeleton of mole-rats (Spalax leucodon Nordmann). Veterinarski Arhiv 72:159-166.

Pinder L. 1996. Marshdeer Blastocerus dichotomus population estimate in the Paraná River, Brazil. Biological Conservation 75:87-91.

Pinder L. \& Grosse A. 1991. Blastocerus dichotomus. Mamm. Species 380: $1-4$.

Piovezan U. 2004. História natural, área de vida, abundância de Blastocerus dichotomus (Illiger, 1985) (Mammalia, Cervidae) e monitoramento de uma população à montante da Hidrelétrica Sérgio Motta, Rio Paraná, Brasil. Tese de Doutorado, Universidade de Brasília, Brasília, DF. 80p.

Polegato B.F. 2008. Determinação dos perfis de estrógenos e progestinas fecais durante o ciclo estral, gestação e período pós-parto em cervos-do-pantanal (Balstocerus dichotomus) em cativeiro. Dissertação de Mestrado, Universidade Estadual Paulista, Jaboticabal, SP. 74p.

Rajani C.V., Chandrasekhar L., Chandy G. \& Chungath J.J. 2013. Anatomical studies on the bones of the pelvic limb in Indian muntjac (Muntiacus muntjak). Tamilnadu J. Vet. Anim. Sci. 44:21-25.

Ribeiro P.R.Q., Santos A.L.Q., Souza R.R., Pereira S.G., Borges D.C.S., Ribeiro L.A. \& Souza T.A.M. 2013. Anatomia óssea do cíngulo pélvico, da coxa e da perna do tamanduá bandeira Myrmecophaga tridactyla (Myrmecophagidae: Pilosa). Biotemas 26:153-160.

Ríos-Uzeda B. 2008. Estimativa populacional, seleção de habitat, distribuição e conservação do cervo-do-pantanal nas savanas do norte da Bolívia. Dissertação de Mestrado, Universidade Federal do Mato Grosso do Sul, Campo Grande, MS. 82p.

Rodrigues H. 2005. Técnicas Anatômicas. $3^{a}$ ed. GM Gráfica e Editora, Vitória, ES. 229p.

Tiepolo L.M., Fernandez F.A.S. \& Tomas W.M. 2004. A conservação da população do cervo do pantanal Blastocerus dichotomus (Illeger, 1915) (Mammalia, Cervidae) no Parque Nacional de Ilha Grande e entorno (PR/MS). Natureza e Conservação 2:56-66.

Tomas W.M., Beccaceci M.D. \& Pinder L. 1997. Cervo-do-pantanal (Blastocerus dichotomus), p.24-40. In: Barbanti Duarte J.M. (Ed), Biologia e Conservação de Cervídeos Sul-Americanos: Blastocerus, Ozotoceros e Mazama. Funep, Jaboticabal, SP. 238p. 